\title{
An updated catalogue of the Geometridae (Lepidoptera: Geometroidea) from Chile. Part I: Archiearinae, Geometrinae and Sterrhinae
}

\section{Catálogo actualizado de los Geometridae (Lepidoptera: Geometroidea) de Chile. Parte I: Archiearinae, Geometrinae y Sterrhinae}

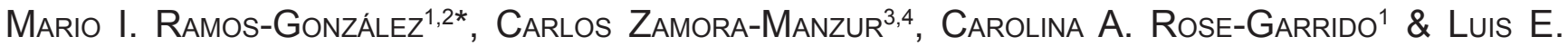 \\ PARRA ${ }^{1}$
}

${ }^{1}$ Departamento de Zoología, Facultad de Ciencias Naturales y Oceanográficas, Universidad de Concepción, Casilla 160-C, Concepción, Chile.

2Programa de Magíster en Ciencias mención Zoología, Departamento de Zoología, Facultad de Ciencias Naturales y Oceanográficas, Universidad de Concepción, Chile.

${ }^{3}$ Departamento de Ecología, Facultad de Ciencias, Universidad Católica de la Santísima Concepción, Alonso de Rivera 2850, Concepción, Chile.

${ }^{4}$ Programa de Doctorado en Sistemática y Biodiversidad, Facultad de Ciencias Naturales y Oceanográficas, Universidad de Concepción, Chile.

*Email: marioramos@udec.cl

\begin{abstract}
The Geometridae are the second most diverse family of Lepidoptera. Seven subfamilies of geometrid moths have been recognized worldwide, and five of those have been recorded in Chile. The highest species richness of Chilean Geometrids is concentrated in Ennominae and Larentiinae, subfamilies that will be treated in subsequent volumes of this catalog. The earlier catalogue of the Chilean geometrid moths was published by Angulo \& Casanueva (1981), who listed species with no more records that type locality and some flight periods. Since then, much of the taxonomic knowledge has changed, resulting in new combinations and descriptions of numerous new species, as well as establishing new species records for Chile. For each species, we include BIN number (if available), synonymy, biological data, host, references, known geographical distribution, flight period and reference photographs of species. In order to obtain both old and new data, we used specimens from different national and international scientific collections. The result was a review of 13 geometrid moths, which represent the three less known subfamilies of this group in Chile: Archiearinae, Geometrinae and Sterrhinae.
\end{abstract}

KeYwords: Distribution, Flight period, Host plants, New records, Taxonomy.

\section{RESUMEN}

Los Geometridae son la segunda familia más diversa de Lepidoptera. Siete subfamilias de geométridos han sido reconocidas en todo el mundo, y cinco de ellas han sido registradas en Chile. La mayor riqueza de especies de geométridos chilenos se concentra en Ennominae y Larentiinae, subfamilias que se tratarán en volúmenes posteriores de este catálogo. El anterior catálogo de geométridos chilenos fue publicado por Angulo \& Casanueva (1981), quienes enumeraron las especies con no más registros que la localidad tipo y algunos períodos de vuelo. Desde entonces, gran parte del conocimiento taxonómico ha cambiado, dando como resultado nuevas combinaciones y descripciones de numerosas especies nuevas, así como el establecimiento de nuevos registros de especies para Chile. Para cada especie, incluimos el número de BIN (si está disponible), la sinonimia, los datos biológicos, hospederos, referencias bibliográficas, distribución geográfica conocida, período de vuelo y fotografías de referencia de las especies. Con el fin de obtener datos antiguos y nuevos, utilizamos muestras de diferentes colecciones científicas nacionales e internacionales. El resultado fue una revisión de 13 geométridos, los que representan las tres subfamilias menos conocidas de este grupo en Chile: Archiearinae, Geometrinae y Sterrhinae.

Palabras clave: Distribución, Períodos de vuelo, Plantas hospederas, Nuevos registros, Taxonomía. 


\section{INTRODUCTION}

Approximately 1200 extant species of Lepidoptera occur in Chile (Parra \& Villagrán-Mella 2008). Geometridae are the most diverse family of Lepidopterans in Chile with an estimated species richness of 450 species and exhibit the highest degree of endemism, with $88 \%$ of species being endemic to Chile (Parra 1995; Parra \& Villagrán-Mella 2008).

Geometrid moths have a strong association with their larval food plants. Due to the high specificity and dependence of particular plants to develop through their ontogenetic cycle (Bodner et al. 2010; Brehm \& Fiedler 2005; Scoble 1995), Geometridae are more diverse in those vegetational formations that include arboreal stratum and bush (Bocaz et al. 2003; Scoble 1995). In Chile, geometrid moths are distributed throughout the country but they are especially abundant in temperate forests, mainly between the regions of Biobío and Los Lagos (Hausmann \& Parra 2009; Zamora-Manzur et al. 2011). Chilean species are mostly associated with native vegetation (Beéche et al. 1987; Bocaz et al. 2003; Bocaz \& Parra 2005; Parra \& Ibarra-Vidal 1997); however, the knowledge of the natural history of a vast number of them are still unknown.

Chilean Geometridae are belong to five subfamilies. In this catalog we include the three less diverse and poorly studied subfamilies with regard to the fauna of Geometridae of Chile: Archiearinae, Geometrinae and Sterrhinae. The remaining subfamilies (Ennominae and Larentiinae) will be treated in later volumes of this catalogue.

The study of the Chilean Geometridae fauna began in the mid-nineteenth century with the work of Blanchard (1852), in which described the first Sterrhinae from Chile. In turn, Butler (1882) described several new species of Sterrhinae based on material collected mainly in Valparaiso. Subsequently, the first Chilean species of Archiarinae and Geometrinae were described by Butler (1882), followed by subsequent descriptions of further species by Butler (1883) and Fletcher (1953).

The first list of the Chilean Lepidoptera was published by Bartlett-Calvert (1886), including 86 genera and 166 species of geometrid moths. Later, further lists and catalogues have been compiled that comprise information on the Chilean Geometridae (Angulo \& Casanueva 1981), and geometrid moths of the world (Scoble 1999). However, the taxonomic knowledge is continually changing and a considerable number of taxonomic revisions have been published subsequently (e.g., Parra \& Hernández 2010; Parra et al. 2017). Our aim is to provide an up-to-date taxonomic catalogue of the Geometridae of Chile, with annotations including BIN numbers, synonyms, information about type material, references and new data about the distribution and biology of the species.

\section{MATERIALS AND METHODS}

We conducted an exhaustive search of literature about Chilean geometrid moths, complemented by information from collections and museums. The information collected is presented as a catalogue of the Geometridae of Chile with an emphasis on the currently valid taxonomic combination, synonyms, type species of each genus, type localities, depository institutions of type material, known distributions, flight periods, host plants and specific references for additional information, such as genitalia and preimaginal stages. The Chilean biological material examined in this study is part of the entomological collections from: Museo de Zoología de la Universidad de Concepción, Muséum National d'Histoire Naturelle, British Museum of Natural History, Zoologische Staatssammlung München, and Colección Entomológica de la Universidad de Tarapacá. The flight period and distribution were adopted from literature and complemented with the information of specimen labels from aforementioned museums (see Appendix 1 for details).

AbBreviations

AMNH American Museum of Natural History, New York, USA

BMNH Natural History Museum, London, UK (formerly British Museum)

CBG Centre for Biodiversity Genomics, University of Guelph, Ontario, Canada

CNC Canadian National Collection of Insects, Arachnids and Nematodes, Canada

ETHZ Entomological Collection of Eidgenössische Technische Hochschule Zürich, Switzerland

IDEA Colección Entomológica de la Universidad de Tarapacá, Arica, Chile

LSL Linnean Society of London, UK

MNHNP Muséum National d'histoire naturelle, París, France

MZUC-UCCC Museo de Zoología de la Universidad de Concepción, Concepción, Chile

NHRS Naturhistoriska Riksmuseet, Stockholm, Sweden

USNM National Museum of Natural History, Smithsonian Institution, Washington DC, USA

ZMUC Zoological Museum, University of Copenhagen, Copenhagen, Denmark

ZSM Zoologische Staatssammlung München, München, Germany 


\section{RESULTS}

In Chile, the less diverse subfamilies of Geometridae, Archiearinae, Geometrinae and Sterrhinae, are represented only by 8 genera and 13 valid species. Archiearinae are represented by 2 genera and 3 species: one genus is endemic to Chile and the other is shared with Argentina. The Geometrinae are represented only by 1 genus and 1 species, which is also distributed in Bolivia and Argentina. The subfamily Sterrhinae are represented by 9 species and 5 genera, of which one genus is exclusively Neotropical while the rest have a Palearctic or cosmopolitan distribution. Particularly, in this subfamily, the species have the broadest distributions within the Chilean geometrid moths. The species list and known information for each species are given below.

\section{TAXONOMY}

Subfamily ArchiEArinae Fletcher, 1953

Archiearides Fletcher, 1953

Type species: Annaphila fidonioides Butler, 1882 (by original designation).

Archiearides fidonioides (Butler, 1882) (Fig. 1A)

No assigned BIN

Annaphila fidonioides Butler, 1882a: 137; BartlettCalvert, 1886: 329.

Archiearides fidonioides (Butler, 1882). Fletcher, 1953: 370, pl. 1, 30, 31; figs. 1, 3-5; Scoble, 1999: 60.

Type locality: CHILE: Valparaíso, Las Zorras.

Type material: Syntype (1 + ), deposited in BMNH.

Distribution: CHILE: Valparaíso to Malleco, mainly foothill zone of the Andes Mountains (MZUC-UCCC data). ARGENTINA: Neuquén (ZSM data).

Flight period: September to January (MZUC-UCCC data; Butler, 1882a).

Genitalia: Fletcher, 1953: figs 3-5.

Remarks: Host plants and preimaginal stages are unknown.

\section{Archiearides pusilla (Butler, 1883) (Fig. 1B)}

No assigned BIN

Archiearis pusilla Butler, 1883: 87; Bartlett-Calvert, 1886: 329.

Archiearides pusilla (Butler, 1883). Fletcher, 1953: 370; Angulo \& Casanueva, 1981:10; Scoble, 1999: 60.

Type locality: CHILE: Valparaíso.

Type material: Syntype (1ㅇ), deposited in BMNH.

Distribution: CHILE: Valparaíso to Melipilla (Butler, 1883; ZSM-data)

Flight period: Summer (Butler, 1883); October (ZSM-data). Remarks: Genitalia, host plants and preimaginal stages are unknown.
Lachnocephala Fletcher, 1953

Type species: Lachnocephala vellosata Fletcher, 1953 (by original designation).

Lachnocephala vellosata Fletcher, 1953 (Fig. 1C)

No assigned BIN

Lachnocephala vellosata Fletcher, 1953:368, pl. 1, figs. 28, 29, fig 2, 6-8; Angulo \& Casanueva, 1981: 10; Scoble, 1999: 530.

Type locality: CHILE: Coquimbo.

Type material: Holotype ( $1 \hat{\jmath})$, Allotype (1q) and Paratypes $(2 \hat{\jmath}, 4$ ㅇ) deposited in BMNH.

Distribution: CHILE: Elqui to Cordillera (MZUC-UCCC data).

Flight period: September to October (MZUC-UCCC data). Genitalia: Fletcher, 1953: figs 6-8.

Remarks: Host plants and preimaginal stages are unknown.

Subfamily Geometrinae Leach, 1815

Anomphax Warren, 1909

Type species: Omphax gnoma Butler, 1882b (by original designation).

Anomphax gnoma (Butler, 1882) (Fig. 1D)

No assigned BIN

Omphax gnoma Butler, 1882b: 367; Bartlett-Calvert, 1886: 330; Izquierdo, 1895: 815, pl. 3, fig. 12; Angulo \& Casanueva, 1981: 22.

Anomphax gnoma (Butler, 1882). Warren, 1909: 75; Prout, 1910: 212; Pitkin, 1996: 328, figs. 1, 63, 86, 136, 185, 227; Scoble, 1999: 45.

Type locality: CHILE: Valparaíso, Las Zorras.

Type material: Lectotype (19), deposited in BMNH.

Distribution: CHILE: Valparaíso to Araucanía (Izquierdo 1895). ARGENTINA: Salta (Prout 1910). BOLIVIA (Pitkin 1996).

Flight period: September, October (MZUC-UCCC data), November to March (Izquierdo, 1895), May (MZUCUCCC data).

Genitalia: Pitkin, 1996: figs 63, 86, 136, 185, 227, 328.

Host plants: Anacardiaceae: Schinus polygamus (Cav.) (Izquierdo 1895), Schinus molle L. (MZUC-UCCC data).

Preimaginal stages: Izquierdo (1895): 816 (larva and pupa). Life cycle: Izquierdo (1895) indicated that the pupal stage lasted 14 days (from the 6th to the 20th of February). A specimen collected by M. Hengst (deposited in MZUCUCCC) was bred from larva to imago and the following times were recorded: larva collected from Schinus molle on 21-IX-1997, pupa formed on 29-IX-1997 and emerged after 21 days (20-X-1997); these data correspond to new biological records for the species (flight period, host plant and life cycle). 


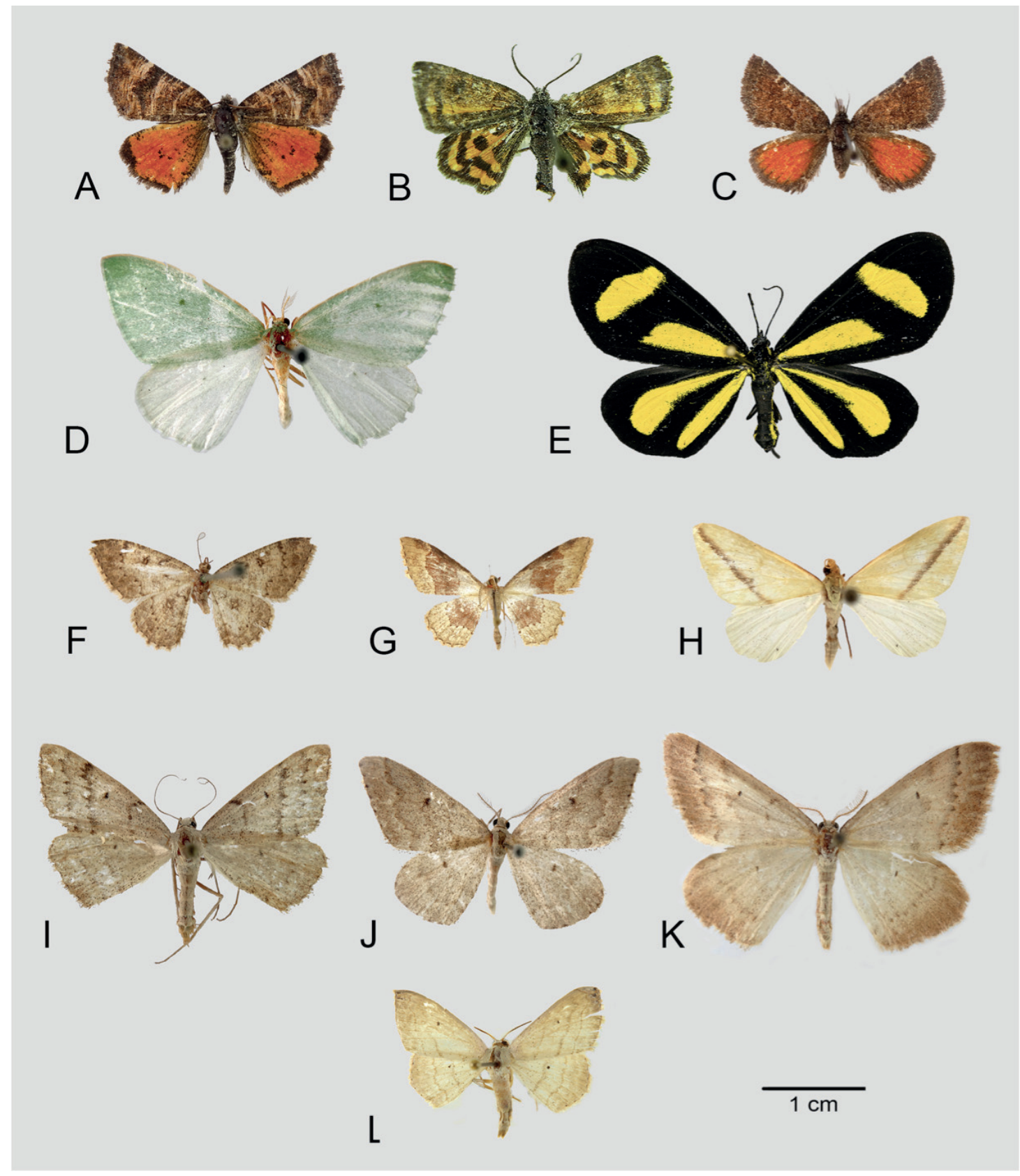

Figure 1: Imagoes in dorsal view of Chilean Geometrinae, Archiearinae and Sterrhinae. a) Archiearides fidonioides (Butler); b) A. pusilla (Butler), photo courtesy of Axel Hausmann; c) Lachnocephala vellosata Fletcher; d) Anomphax gnoma (Butler); e) Cyllopoda claudicula (Dalman), photo courtesy of Andrey Zheludev; f) Cyclophora nanaria (Walker); g) C. semirosea (Butler); h) Rhodometra sacraria (Linnaeus); i) Rhodostrophia cauquenensis (Butler); j) R. chilenaria (Blanchard); k) R. ferruginaria (Blanchard); 1) Scopula umbilicata (Fabricius), extracted and modified from BOLD Sample ID: CCDB-20265-D01CBG (Photography Group, Centre for Biodiversity Genomics, CreativeCommons - Attribution Non-Commercial Share-Alike (2013)). Scale bar = 1 cm. See Appendix 1 for specimens data (*). / Imagos en vista dorsal de Geometrinae, Archiearinae y Sterrhinae chilenos. a) Archiearides fidonioides (Butler); b) A. pusilla (Butler), fotografía cortesía de Axel Hausmann; c) Lachnocephala vellosata Fletcher; d) Anomphax gnoma (Butler); e) Cyllopoda claudicula (Dalman), fotografía cortesía de Andrey Zheludev; f) Cyclophora nanaria (Walker); g) C. semirosea (Butler); h) Rhodometra sacraria (Linnaeus); i) Rhodostrophia cauquenensis (Butler); j) R. chilenaria (Blanchard); k) R. ferruginaria (Blanchard); 1) Scopula umbilicata (Fabricius), fotografía extraída y modificada de BOLD, ID de la muestra: CCDB-20265-D01CBG (Photography Group, Centre for Biodiversity Genomics, CreativeCommons - Attribution Non-Commercial Share-Alike (2013)). Escala = $1 \mathrm{~cm}$. Ver Apéndice 1 para los datos de los especímenes $(*)$. 
Subfamily Sterrhinae Meyrick, 1892

Cyclophora Hübner, 1822

Type species: Phalaena albipunctata Hufnagel, 1767 (by subsequent designation by Moore (1887)).

\section{Cyclophora nanaria (Walker, 1861) (Fig. 1F)}

BIN: BOLD:AAD6021

Ephyra nanaria Walker, 1861: 633.

Zonosoma nanularia Herrich-Schäffer, 1870: 180

Ephyra obscura Druce, 1898: 536, pl. 99, fig. 6.

Euephyra serrulata Packard, 1873: 73.

Leucophthalmia serrulata (Packard, 1873). Artigas, 1994: 516.

Cyclophora serrulata (Packard, 1873). Vargas, 1979: 295.

Cyclophora nanaria (Walker, 1861). Scoble, 1999: 206; Vargas et al. 2001: 25, fig. 1-8.

Type locality: REPÚBLICA DOMINICANA: Santo Domingo for nanaria Walker. CUBA for nanularia HerrichSchäffer. MÉXICO: Presidio de Mazatlán, Durango for obscura Druce. USA: Texas for serrulata Packard.

Type material: nanaria Holotype (q), deposited in BMNH; nanularia Syntype(s) (ठ), unknown depository; obscura Syntypes ( $\left.{ }^{\Uparrow}\right)$, deposited in BMNH; serrulata Syntype (ㅇ), unknown depository.

Distribution: USA to Argentina. CHILE: Arica to Santiago (Vargas et al. 2001).

Flight period: October for Chile (MZUC-UCCC data; Vargas et al. 2001); May to March in the northern distribution (CNC data; ZSM data; CBG data).

Genitalia: Vargas et al. 2001: figs 7a-b, 8.

Host plants: Asteraceae: Ageratum conyzoides L., Bigelowia spp., Encelia califórnica Nutt., Parthenium hysterophorus L.; Fabaceae: Acacia spp. (Scoble 1999). For Chile, has been registered in Oleaceae: Olea europaea L.; Anacardiaceae: Schinus molle L. (Vargas 1979; Vargas et al. 2001); Mimosaceae: Prosopis tamarugo Phil. (Vargas et al. 2001) and Fabaceae: Acacia macracantha Willd. (Vargas \& Parra 2009).

Preimaginal stages: Vargas et al. (2001): 26 (egg), 26 (larva), 27 (pupa).

Life Cycle: Vargas et al. (2001) indicated that the species has a multivoltine life-cycle, in which each generation needs 45-50 days to complete: embryonic development (5-6 days), larval period (20 days), pupal period (12-14 days) and adult period (10 days).

\section{Cyclophora semirosea (Butler, 1882) (Fig. 1G)}

\section{BIN: BOLD:AAF1904}

Ephyra semirosea Butler, 1882b: 368; BartlettCalvert, 1886: 341; Angulo \& Casanueva, 1981: 20 (as a junior synonym of $E$. notigera Butler).

Ephyra notigera Butler, 1882b: 368. Bartlett-
Calvert, 1886: 341; Angulo \& Casanueva, 1981: 20. Cyclophora semirosea (Butler, 1882). Scoble, 1999: 207.

Type locality: CHILE: Valparaíso for semirosea Butler and notigera Butler.

Type material: semirosea Syntype deposited in BMNH; notigera Syntype deposited in BMNH.

Distribution: CHILE: Tarapacá to Coyhaique (MZUCUCCC data; ZSM data).

Flight period: September to March (MZUC-UCCC data).

Remarks: Genitalia, host plants and preimaginal stages are unknown.

\section{Cyclophora umbrata (Butler, 1882)}

No assigned BIN

Ephyra umbrata Butler, 1882b: 368; Bartlett-Calvert, 1886: 341; Angulo \& Casanueva, 1981: 20.

Cyclophora umbrata (Butler, 1882). Scoble, 1999: 208.

Type locality: CHILE: Valparaíso.

Type material: Syntype, deposited in BMNH.

Distribution: CHILE: Valparaíso (Butler 1882b).

Flight period: December (Butler 1882b).

Remarks: Genitalia, host plants and preimaginal stages are unknown. Probably a junior synonym of $C$. nanaria Walker.

\section{Cyllopoda Dalman, 1823}

Type species: Bombyx claudicula Dalman, 1823 (by monotypy).

\section{Cyllopoda claudicula (Dalman, 1823) (Fig. 1E)}

No assigned BIN

Bombyx (Cyllopoda) claudicula Dalman, 1823: 102;

Walker, 1856: 1778; Kirby, 1892: 403; Prout, 1916: 173; Prout, 1934: 132; Sick, 1937: 400-412.

Callimorpha dichroa Perty, 1833: 161.

Chrysauge dichroa (Perty, 1833). Walker, 1854: 371; Kirby, 1892.

Cyllopoda dichroa (Perty, 1833). Prout, 1916: 174.

Flavinia dichroa (Perty, 1833). Strand, 1920: 136.

Atyria dichroa (Perty, 1883). Scoble, 1999: 77.

Cyllopoda claudicula catabathmus Prout, 1938: 120; Scoble, 1999: 214.

Cyllopoda claudicula catabathmus ab. filigera Prout, 1938: 120.

Cyllopoda claudicula claudicula (Dalman, 1823). Prout, 1938: 120; Scoble, 1999: 214.

Cyllopoda claudicula (Dalman, 1823). Lewis \& Covell, 2008: 90, figs. 2E-F, 3A, 4A.

Type locality: BRAZIL: Brazil for claudicula Dalman; Blumenau, Santa Catarina for catabathmus Prout; Río 
Negro for dichroa Perty.

Type material: claudicula Lectotype $(1 \widehat{\jmath})$, deposited in

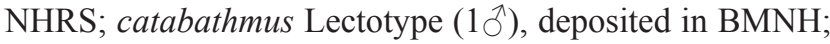
dichroa Syntype(s), unknown depository.

Distribution: BRAZIL: Santa Catarina to Rio de Janeiro. CHILE, no further data. (Lewis \& Covell 2008).

Flight period: August (ETHZ data).

Genitalia: Lewis \& Covell, 2008: figs 3A, 4A.

Host plants: Arboreal plants (Sihvonen \& Kaila 2004).

Remarks: Preimaginal stages unknown. This species has only been reported for Chile by Lewis \& Covell (2008), based on a single male specimen deposited in AMNH whose label reads "1939 / Chile". This record is doubtful and requires confirmation because the climate of Chile differs strongly from the humid habitats where this species is typically found.

\section{Rhodometra Meyrick, 1892}

Type species: Phalaena sacraria Linnaeus, 1767 (by subsequent designation by Lhomme (1930)).

\section{Rhodometra sacraria (Linnaeus, 1767) (Fig. 1H)} BIN: BOLD:AAA8983

Phalaena (Geometra) sacraria Linnaeus, 1767: 863

Phalaena fulvaria Fabricius, 1794: 160.

Phalaena (Geometra) labda Cramer, 1777: 129, pl. 181, fig. D.

Aspilates minervae Gistel, 1856: 349.

Pyralis sacralis Thunberg, 1784: 14.

Phalaena (Geometra) sanguinaria Esper, 1801: 173, pl. 30, figs. 10, 11.

Aspilates lividaria Costa, 1848: 365, pl. 5, fig. 2.

Rhodometra plectaria debiliaria Rothschild, 1914: 345.

Sterrha (Rhodometra) sacraria var. desertorum Stauder, 1914: 172, fig. 13.

Rhodometra sacraria (Linnaeus, 1767). Scoble, 1999: 820; Hausmann, 2004: 429.

Type locality: NORTH AFRICA: "Barbaria" for sacraria Linnaeus. SURINAM: Surinam for labda Cramer. ARGELIA: Guelt-es-Stel for plectaria debiliaria Rothschild; Biskra, El Kantara for sacraria var. desertorum Stauder. ITALY: Italy for fulvaria Fabricius; Naples for sanguinaria Esper and lividaria Costa. GREECE: Athens, Temple of Minerva for minervae Gistel. SWEDEN: Sweden for sacralis Thunberg.

Type material: sacraria Syntype, deposited in LSL; labda Syntype, unknown depository; plectaria debiliaria Holotype $\left(\delta^{\top}\right)$, deposited in BMNH; sacraria var. desertorum Syntype (5今, 6ㅇ), unknown depository; fulvaria Syntype, lost; sanguinaria Syntype, unknown depository; lividaria Costa, Syntype, unknown depository; minervae Syntype, unknown depository; sacralis Syntype, unknown depository.
Distribution: Migratory cosmopolitan species (Hausmann 2004). CHILE: Petorca to Ñuble (MZUC-UCCC data; ZSM data).

Flight period: January to April (King \& Viejo Montesinos 2014).

Genitalia: Hausmann, 2004: fig 193.

Host plants: Asteraceae: Anthemis spp.; Anacardiaceae: Rhus spp.; Polygonaceae: Emex spp., Oxygonum spp., Polygonum spp., Rumex spp.; Rosaceae: Malus pumila Mill. (Scoble 1999).

Preimaginal stages: egg, larva and pupa (Skule 1980; Grosser \& Meier 1986; Patocka 2003; King 2013).

Remarks: Species with multivoltine life-cycle reported (Hausmann 2004).

\section{Rhodostrophia Hübner, 1823}

Type species: Phalaena calabra Petagna, 1786, by subsequent designation by Hampson (1895a).

\section{Rhodostrophia cauquenensis (Butler, 1882) (Fig. 1I)} No assigned BIN

Psamatodes cauquenensis Butler, 1882b: 382; Bartlett-Calvert, 1886: 335; Angulo \& Casanueva, 1981: 23; Scoble, 1999: 994 (inc. sed.).

Rhodostrophia dentilineata Warren, 1895: 99.

Rhodostrophia cauquenensis (Butler, 1882). Trusch \& Hausmann 2008: 7.

Type locality: CHILE: Chile for dentilineata Warren; Colchagua, Mountains of the "Hacienda de Cauquenes" for cauquenensis Butler.

Type material: cauquenensis Holotype ( $)$, deposited in BMNH; dentilineata Syntypes (4^), deposited in BMNH. Distribution: CHILE: Petorca to Biobío (MZUC-UCCC data).

Flight period: December to April (MZUC-UCCC data)

Remarks: Genitalia, host plants and preimaginal stages are unknown.

Rhodostrophia chilenaria (Blanchard, 1852) (Fig. 1J) BIN: BOLD:AAF7291 Acidalia chilenaria Blanchard, 1852: 95 pl. 7, fig, 11; Scoble, 1999: 994 (inc. sed.).

Psamatodes chilenaria (Blanchard, 1852). Butler, 1882b: 382, pl. 16, fig. 6; Angulo \& Casanueva, 1981: 23 .

Rhodostrophia obscura Warren, 1900: 164.

Rhodostrophia chilenaria (Butler, 1882). Trusch \& Hausmann 2008: 7.

Type locality: CHILE: Chile for chilenaria Blanchard and obscura Warren.

Type material: chilenaria Syntype (1\%), deposited in MNHNP; obscura Holotype (1§), deposited in BMNH. 
Distribution: Copiapó to Cordillera (MZUC-UCCC data; ZSM data).

Flight period: August to May (MZUC-UCCC data; ZSM data).

Remarks: Genitalia, host plants and preimaginal stages are unknown.

\section{Rhodostrophia ferruginaria (Blanchard, 1852) (Fig. 1K) BIN: BOLD:AAX9112}

Acidalia ferruginaria Blanchard, 1852: 96, pl. 7, fig. 11; Scoble, 1999: 994 (inc. sed.).

Psamatodes ferruginaria (Blanchard, 1852). Butler, 1882b: 381, pl. 16, fig. 7; Bartlett-Calvert, 1886: 335; Angulo \& Casanueva, 1981: 24.

Rhodostrophia ferruginaria (Butler, 1882). Trusch \& Hausmann, 2008: 7.

Type locality: CHILE: Cordillera de Elqui.

Type material: Syntype(s), unknown depository. Distribution: Curicó to Cautín (MZUC-UCCC data).

Flight period: November to February (MZUC-UCCC data). Remarks: Genitalia, host plants and preimaginal stages are unknown. It was not possible to corroborate the presence of the syntype specimens of this species along with the other types of Chilean Geometridae described by Blanchard in the MNHNP. Probably the types of this species are lost.

\section{Scopula Schrank, 1802}

Type species: Phalaena paludata Linnaeus, 1767, by subsequent designation by Prout (1906).

\section{Scopula umbilicata (Fabricius, 1794) (Fig. 1L)}

BIN: BOLD:AAA9025

Phalaena umbilicata Fabricius, 1794: 203.

Acidalia umbilicata (Fabricius, 1794). Guenée, 1858:

504; Walker, 1861: 727; Hulst, 1895: 72; Aurivillius,

1897: 166; Oberthur, 1916: 173, pl. 401, fig. 3445;

Barnes \& McDunnough, 1917: 102.

Craspedia umbilicata (Fabricius, 1794). Hampson, 1895b: 331

Synelys umbilicata (Fabricius, 1794). Hulst, 1896: 300; Dyar, 1903: 293; Grossbeck, 1917: 89.

Craspedia crenatilinea Warren, 1901: 454.

Craspedia cugia Schaus, 1901: 253.

Acidalia indoctaria Walker, 1861: 731; Barnes \& McDunnough, 1917: 102.

Acidalia nigroapicata Thierry-Mieg, 1892: 235.

Scopula umbilicata peruviana Prout, 1922: 338.

Scopula umbilicata (Fabricius, 1794). Kaye \& Lamont, 1927: 109; Prout, 1934: 222; Covell, 1970: 129, figs. 12, 33, 54, 77; Scoble, 1999: 867; Vargas \& Hausmann, 2008: 167.

Type locality: WEST INDIES: Americae meridionalis Ins. for umbilicata Fabricius. MEXICO: Orizaba for cugia Schaus. PANAMA: Chiriquí for nigroapicata Thierry-Mieg. Venezuela for indoctaria Walker. PERU: Huamachuco, $3200 \mathrm{ft}$. for crenatilinea Warren; Barranco (near Lima) for umbilicata peruviana Prout.

Type material: umbilicata Holotype (ठ̂), deposited in ZMUC; cugia Syntype (1\%) deposited in USNM; nigroapicata Syntype (2 $\hat{0})$, deposited in USNM; indoctaria Holotype (1ठ), deposited in BMNH; crenatilinea Holotype $\left(1{ }^{\top}\right)$, deposited in BMNH; umbilicata peruviana Syntype (19), deposited in BMNH.

Distribution: USA to Chile. CHILE: Arica (Vargas \& Hausmann 2008).

Flight period: February reported for Chile (Vargas \& Hausmann 2008); March to October was reported for its most northern distribution range (Covell 1970).

Genitalia: Covell, 1970: figs 12, 33, 54.

Remarks: Host plants and preimaginal stages are unknown. This highly diverse cosmopolitan genus (more than 700 species in the world (Scoble 1999)) is restricted to one single species in the northern extreme of Chile.

\section{DISCUSSION}

In Chile, the diversity of Geometrinae, Archiearinae and Sterrhinae is very low compared to other countries in South America, unlike Ennominae and Larentiinae. The diversity could increase in at least two emerald moths species in the north of the country (Iquique and Copiapó provinces, at extreme north of Chile), which are still unidentified and possibly new species (Axel Hausmann, pers. comm.), which would increase the diversity of Chilean Geometrinae to 3 species, so it is necessary carry out a further prospection.

Regarding Archiearinae (s. l.), two genera have been reported from the Andean Region: Archiearides and Lachnocephala. According to Young (2006), the Tasmanian Archiearinae are more closely related to Ennominae, particularly Nacophorini, than to the Palearctic Archiearinae (Archiaerinae s. s.). This is probably true with the Andean Archiearinae as well. There have been no studies addressing the phylogenetic relationships within this subfamily; however, the presence of a tympanic accessory with headless ansa and the morphology of the genitalia (e.g., well-developed valvae, V-shaped gnathos, anellus with a pair of processes) seem to indicate that this small group of South American moths would not belong to true Archiearinae, resembling Ennominae instead. However, this hypothesis must be evaluated by a molecular phylogenetic analysis.

In the previous Chilean catalogue, Angulo \& Casanueva (1981) reported two species of Archiearinae, 77 species of Geometrinae and no Sterrhinae. However, their delimitation of subfamilies was incorrect, as species and genera from 
different subfamilies were lumped together (Pitkin 1996; Scoble 1999; Pitkin 2002). Thus, the subfamily Geometrinae (sensu Angulo \& Casanueva 1981) in fact comprised 1 species of Geometrinae, 52 species of Ennominae, 19 species of Larentiinae and 5 species of Sterrhinae. Later, Scoble (1999) compiled the information of all hitherto described Geometridae, indicating only information about references, synonyms, type localities and depositories of the type material. Because not all Chilean geometrid moths were originally described in Chile, the count of Archiearinae, Geometrinae and Sterrhinae were three, one and five species ( 3 of them incertae sedis) respectively. Finally, in this catalogue we recognize 8 genera and 13 valid species of these subfamilies, updating both the number of species and the knowledge of this little group of geometrid moths in Chile.

\section{ACKNOWLEDGMENTS}

The authors thanks M.J. Scoble and L. Pitkin (BMNH) for their assistance during Parra's visit to The Natural History Museum. We also thank A. Hausmann for allowing access to Chilean material deposited in ZSM and use of some photographs of specimens of the collection. Andrey Zheludev for allowing use a picture for the plate. The Museo de Zoología de la Universidad de Concepción, Chile provided dissected material. Joël Minet (MNHNP) for their cooperation in allowing the study of type specimens, and Adriana Chalup who took the pictures. CZ-M appreciates the financial support of scholarship funding "Beca Doctorado Nacional" CONICYT N 21161423 and project EDPG LPR-161 of Dirección de Postgrado, Universidad de Concepción. MR-G appreciates the financial support of scholarship funding "Beca Magíster Nacional" CONICYT $\mathrm{N}^{\circ} 22162333$. This study was supported by the Research Division of the Universidad de Concepción (Grant 214.113.087-1.0).

\section{REFERENCES}

Angulo, A.O., Casanueva, M.E. 1981. Catálogo de los lepidópteros geométridos de Chile (Lepidoptera: Geometridae). Boletín de la Sociedad de Biología de Concepción 51: 7-39.

Artigas, J.N. 1994. Entomología económica: Insectos de interés agrícola, forestal, médico y veterinario (Nativos, introducidos y susceptibles de ser introducidos). Vol. 2. Ediciones Universidad de Concepción, Concepción, Chile. $943 \mathrm{pp}$.

Aurivillius, C. 1897. Bermerkungen zu den von J. Chr. Fabricius aus Dänischen Sammlungen beschriebenen Lepidopteren. Entomologisk Tidskrift 18: 139-174.

Barnes, W.M., McDunnough, J.H. 1917. Check list of the Lepidoptera of boreal America. Decatur, Illinois, Herald Press. 410 pp.

Bartlett-Calvert, W. 1886. Catálogo de los lepidópteros
Rhopalóceros i Heteróceros de Chile. Anales de la Universidad de Chile 69: 314-352.

BeÉche, M.A., Parra, L.E., Cerda, L.A. 1987. Descripción de estados preimaginales y desarrollo biológico de Omaguacua longibursae Parra \& Beéche, 1986 (Lepidoptera, Geometridae). Boletín de la Sociedad de Biología de Concepción: (Chile) 58: 19-29.

Blanchard, E. 1852. Fauna Chilena - Insectos - Orden VI Lepidópteros. In: Gay, C, (Ed). Historia física y política de Chile: 7: 1-112.

Bocaz, P.A., Parra, L.E. 2005. Revisión y bionomía del género Syncirsodes Butler, 1882 (Lepidoptera: Geometridae). Revista Chilena de Historia Natural 78: 89-111.

Bocaz, P., Parra, L.E., Victoriano, P.F. 2003. Larval morphological variation and its relation to host plants in Syncirsodes primata (Lepidoptera: Geometridae). Gayana 67: 39-44.

Bodner, F., Brehm, G., Homeier, J., Strutzenberger, P., Fiedler, K. 2010. Caterpillars and host plant records for 59 species of Geometridae (Lepidoptera) from a montane rainforest in southern Ecuador. Journal of insect science 10: 1-22.

Brehm, G., Fiedler, K. 2005. Diversity and community structure of geometrid moths of disturbed habitat in a montane area in the Ecuadorian Andes. The journal of research on the Lepidoptera 38: 1-14.

Butler, A.G. 1882a. Heterocerous Lepidoptera collected in Chili by Thomas Edmons, Esq. Part II Noctuites. Transactions of the Entomological Society of London 1882: 113-140.

Butler, A.G. 1882b. Heterocerous Lepidoptera collected in Chili by Thomas Edmons, Esq. Part III Geometrites. Transactions of the Entomological Society of London 1882: 339-423.

Butler, A.G. 1883. Heterocerous Lepidoptera collected in Chili by Thomas Edmonds, Esq. Part IV. Pyrales and Micras. Transactions of the Entomological Society of London 1883: 49-90.

Covell, C.V. 1970. A Revision of the North American Species of the Genus Scopula (Lepidoptera, Geometridae). Transactions of the American Entomological Society 96: 101-221.

Cramer, P. 1777. De uitlandsche Kapellen voorkomende in de drie waereld-deelen Asia, Africa en America, by een verzameld en beschreeven door den heer Pieter Cramer (etc.) Vol 2. Amsteldam \& Baalde. 151 pp.

Dalman, J.W. 1823. Analecta Entomologica. Lindhianus, Holmiae. $108 \mathrm{pp}$.

Druce, H. 1898. Insecta, Lepidoptera, Heterocera Vol. II. In: Godman, F.C., Salvin, O. (Eds), Biologia CentraliAmericana: 1-782. Taylor \& Francis, London.

DYAR, H.G. 1903. A list of North American Lepidoptera and key to the literature of this order of insects. Bulletin of the United States National Museum 52: 1-723.

ESPER, E.J.C. 1801. Die schmetterlinge in Abbildungen nach der Natur mit Beschreibungen. Vol. 5. Erlangen, Germany. $276 \mathrm{pp}$.

FABricius, J.C. 1794. Entomologia systematica emendata et aucta: Secundun classes, ordines, genera, species, adjectis synonimis, locis, observationibus, descriptionibus III, part 2. Hafniae. 472 pp.

Fletcher, D.S. 1953. Some new species of Geometridae from Argentina and Chile. Acta Zoologica Lilloana 13: 367-380. 
Gistel, J. 1856. Die Mysteren der Europäischen Insectenwelt. Druck und Verlag von Tobias Dannheimer, Kempten, Germany. 532 pp.

Grossbeck, J.A. 1917. Insects of Florida, IV: Lepidoptera. Bulletin of the United States National Museum 37: 1-147.

Grosser, N., Meier, G. 1986. Rhodometra sacraria (Linné, 1767) in der DDR (Lepidoptera, Geometridae). Atalanta 17: 147149.

GuenÉE, A. 1858. Uranides et Phalénites I. In: Boisduval, M., Guenée, A. (Eds). Histoire Naturelle des Insectes, Species Général des Lépidoptères 9: 1-514. Librairie Encyclopédique de Roret, Paris.

Hampson, G.F. 1895a. The Fauna of British India, including Ceylon and Burma, Volume III. Taylor and Francis, London. 546 pp.

Hampson, G.F. 1895b On the Geometridae, Pyralidae, and allied families of Heterocera of the Lesser Antilles. The Annals and Magazine of Natural History 7(6): 329-349.

Hausmann, A. 2004. The Geometrid moths of Europe II: Sterrhinae. Apollo Books, Stenstrup, Denmark. 600 pp.

Hausmann, A., Parra, L.E. 2009. An unexpected hotspot of moth biodiversity in Chilean northern Patagonia (Lepidoptera, Geometridae). Zootaxa 1989: 23-38.

Herrich-SchäFfER, G.A.W. 1870. Die Schmetterlinge der Insel Cuba nach natürlichen Exemplaren und Notizen des Herrn Dr. Gundlach in Habana. Correspondenz-Blatt des Zoologisch-Mineralogischen Vereins in Regensburg. 320 pp.

Hulst, G.D. 1895. Notes on types of North American Geometrina in European collections. IV. Entomological News 6: 70-73.

Hulst, G.D. 1896. A classification of the Geometrina of North America, with descriptions of new genera and species. Transactions of the American Entomological Society 23: 245-386.

IzQuierdo, V. 1895. Notas sobre los Lepidópteros de Chile. Anales de la Universidad de Chile 90: 783-835.

Kaye, W.J., Lamont, N. 1927. A catalogue of the Trinidad Lepidoptera Heterocera (moths). Memories of the Department of Agriculture Trinidad and Tobago 3: 1-144.

KING, G.E. 2013. Contribución al conocimiento de la biología y morfología de los estados inmaduros de la subfamilia Sterrhinae Meyrick, 1892 (Insecta: Lepidoptera: Geometridae) en el sur de Madrid. PhD Thesis. Universidad Autónoma de Madrid. España.

KING, G.E., Viejo Montesinos, J.L. 2014. Rhodometra sacraria (Linnaeus), a cosmopolitan Sterrhinae confirmed from Chile (Lepidoptera, Geometridae). Revista Brasileira de Entomologia 58: 103-106.

KIRBY, W.F. 1892. A synonymic catalogue of Lepidoptera Heterocera (Moths), Band 1, Sphinges and Bombyces. Gurney \& Jackson, London. 951 pp.

Lewis, D.S., Covell, C.V.J. 2008. A Review of the Neotropical Genus Cyllopoda (Lepidoptera: Geometridae: Sterrhinae: Cyllopodini). Tropical Lepidoptera Research 18: 88-101.

Linnaeus, C. 1767. Systema Naturae (Ed 12). Holmiae. 532 pp.

Lhomme, L. 1930. Catalogue des Lépidopterès de France et de Belgique I. Le Carriol, par Douelle.

Moore, F. (1887) Lepidoptera of Ceylon. Vol III. Reeve \& Co., London. 578 pp.

OBERTHÜR, C. 1916. Revision iconographique des éspèces de
Phalénites (Geometra, Linne) enumerées et décrites par Achille Guenée, dans les volumes IX et X du Species Général des Lépidoptères, publiés a Paris, chez l'editeur Roret en 1857. In: Oberthür, C. (Ed), Études de lépidopterologie comparée 12: 67-527. Imprimerie Oberthür, Rennes.

PACKARD, A.S. 1873. Descriptions of new American Phalaenidae. Report Peabody Academy of Science 5: 52-81.

PArRA, L.E. 1995. Lepidoptera. In: Simonetti, J.A., Arroyo, M.T.K., Spotorno, A.E., Lozada, E. (Eds), Diversidad biológica de Chile: 269-279. CONICYT, Santiago, Chile.

Parra, L.E., Hernández, C.E. 2010. Estudio filogenético de los géneros de Lithinini de Sudamérica Austral (Lepidoptera, Geometridae): una nueva clasificación. Revista Brasileira de Entomologia 54(1): 1-27.

PARRA, L.E., IBARRA-VIDAL, H. 1997. Taxonomía y notas biológicas de un nuevo género y especie de Geometridae de Chile (Insecta: Lepidoptera). SHILAP Revista Lepidopterologica 25: 53-61.

Parra, L.E., Vargas, H.A., Sanzana, M.J., Hernández, C.E. 2017. Phylogenetic study of the genera of Trichopterygini from Austral South America (Lepidoptera: Geometridae): a new classification. Gayana 81(2): 64-99.

Parra, L.E., Villagrán-Mella, R. 2008. Orden Lepidoptera (mariposas). In: CONAMA (Ed), Biodiversidad de Chile, Patrimonio y Desafíos: 159-165. Chile.

PatockA, J. 2003. Die Puppen der Spanner (Lepidoptera: Geometridae) Mitteleuropas: Unterfamilie Sterrhinae. Bonner zoologische Beitrage: Herausgeber: Zoologisches Forschungsinstitut und Museum Alexander Koenig. Bonner zoologische Beiträge 51: 269-296.

Perty, J.A.M. 1833. Insecta Brasiliensia, fascicle 3. In: Delectus (Ed), Animalium Articulatorum: 125-224. ect. Monachii.

PITKIN, L.M. 1996. Neotropical Emerald moths: a review of the genera (Lepidoptera: Geometridae, Geometrinae). Zoological journal of the Linnean Society 118: 309-440.

PitKIn, L.M. 2002. Neotropical Ennominae moths: a review of the genera (Lepidoptera: Geometridae). Zoological journal of the Linnean Society 135: 121-401.

Prout, L.B. 1906. The generic name Scopula. The entomologist 39: 266-267.

Prout, L.B. 1910. On the Geometridae of the Argentine Republic. Transactions of the Entomological Society of London 1910: 204-345.

Prout, L.B. 1916. New Neotropical Geometridae. Novitates Zoologicae 23: 173-174.

Prout, L.B. 1922. New and little-known Geometridae. Novitates zoologicae 29: 327-363.

Prout, L.B. 1934. Subfamilia Sterrhinae, II. In: Strand, E. (Ed), Lepidopterorum catalogus, part 63. W. Junk, Berlin, Germany.

Prout, L.B. 1938. American Geometridae. In: Seitz, A. (Ed), The Macrolepidoptera of the World 8: 119-121, pl. 17. Kernen, Stuttgart, Germany.

RothschILD, W. 1914. A preliminary account of the Lepidopterous fauna of the Zemplen Mts. (NE Hungary) I- The valley of Kemence stream. Folia Entomologica Hungarica 42(2): 167-184.

Schaus, W. 1901. New species of Geometridae from tropical America. Transactions of the American Entomological Society 27: 165-194, 241-276. 
ScoBle, M.J. 1995. The Lepidoptera: Form, Function and Diversity. Natural History Museum \& Oxford University Press, London. 404 pp.

Scoble, M.J. 1999. Geometrid moths of the world: a catalogue (Lepidoptera, Geometridae). CSIRO Publishing, Natural History Museum, London. 1016 pp.

Sick, F. 1937. Senckenbergiana 19: 400-412.

Sihvonen, P., Kaila, L. 2004. Phylogeny and tribal classification of Sterrhinae with emphasis on delimiting Scopulini (Lepidoptera: Geometridae). Systematic Entomology 29: 324-358.

SkULE, B. 1980. Rhodometra sacraria L. Lidt om artens biologi og udbredelse, samt om den anden europaeiske Rhodometraart: Rhodometra anthophilaria $\mathrm{Hb}$. Lepidoptera (København) 3: 261-268.

Stauder, H. 1914. Lepidopterologische Ergebnisse zweier Sammelreisen in den algerischen Atlas und die nördliche Sahara. Zeitschrift für Wissenschaftliche Insektenbiologie 10: 167-175.

Strand, E. 1920. Beiträge zur Kenntnis exotischer Heterocera und Grypocera. Archiv fur Naturgeschichte 86A(7): 137.

Thierry-Mieg, P. 1892. Descriptions de lépidoptères nocturnes. Le Naturaliste: Revue Illustrée: Des Sciences Naturelles 14: 216-217, 235-236, 262.

Thunberg, C.P. 1784. Dissertatio Entomologica sistens Insecta Suecica Vol. 1. Uppsala. 114 pp.

Trusch, R., Hausmann, A. 2008. New species of the genus Rhodostrophia Hübner, 1823 from Iran (Geometridae: Sterrhinae). Nota Lepidopterológica 30(1): 7-16.

VARGAS, H.C. 1979. Tres nuevas plagas entomológicas para Chile. IDESIA 5: 295-296.
Vargas, H.A., Hausmann, A. (2008) Adiciones a la Fauna de Geométridos (Lepidoptera: Geometridae) de Chile. Neotropical Entomology 37: 167-168.

Vargas, H.A., Parra, L.E. 2009. Prospección de lepidópteros antófagos asociados a Acacia macracantha Willd. (Fabaceae) en el norte de Chile. Revista Brasileira de Entomologia 53: 291-293.

Vargas, H.A., Vargas, H.E., Bobadilla, D.E., Parra, L.E. 2001. Notas sobre la polilla de la flor del olivo Cyclophora nanaria Walker (Lepidoptera: Geometridae; Sterrhinae). IDESIA 19: 25-33.

WALKER, F. 1854. List of the specimens of lepidopterous insects in the collection of the British Museum 2: 369-371. London.

WALKER, F. 1856. List of specimens of lepidopterous insects in the collection of the British Museum 7: 1510-1808. London.

Walker, F. 1861. Part. XXII: Geometrites (continued). In: Gray, J.E., Walker, F. (Eds), List of the specimens of Lepidopterous insects in the collection of the British Museum: 500-1280. Printed by order of the Trustees, London.

WARren, W. 1895. New species and genera of Geometridae in the Tring Museum. Novitates Zoologicae 2: 82-159.

WARren, W. 1900. New genera and species of American Drepanulidae, Thyrididae, Epiplemidae and Geometridae. Novitates zoologicae 7: 117-225.

Warren, W. 1901. New American moths. Novitates Zoologicae 8: 435-493.

WARREN, W. 1909. New American Uraniidae and Geometridae in the Tring Museum. Novitates Zoologicae 16: 69-109.

Zamora-Manzur, C., Parra, L.E., Jaque, E. 2011. Patrones de distribución de los geométridos de la Región del Biobío, Chile: Una aproximación para su conservación. Revista Chilena de Historia Natural 84: 465-480.

\section{APPENDIX 1}

Summary data for 190 specimens studied in this article, as obtained from the labels. Information is provided for countries and provinces (highlighted in bold), the collection or museum (in parentheses), number of specimens studied (in parentheses) and if the studied specimen belonged to type material (in square brackets). The photographed specimens shown on Figure 1 are indicated by an asterisk (*).

\section{ARCHIEARINAE}

Archiearides fidonioides: CHILE: Valparaíso: Chili, Valparaíso, Las Zorras XII-I Leg. T. Edmonds [Syntype] (BMNH). Santiago: Peñalolen 22-X-1950 coll. n.n. Cordillera: Farellones 28-X-2000 Leg. M. Beéche (*). Melipilla: Alhué 17-IX-1947 Leg. Barros (2 specimens); Alhué 18-IX-1947 Leg. Barros (3 specimens). Nuble: Las Trancas 26-XI-2000 Leg. M. Beéche. Malleco: Corralco 08XII-2014 Leg. Rose \& Parra (7 specimens); Corralco 05-XII-2017 Leg. L.E. Parra (8 specimens); Curacautín 15-XII-1950 Leg. n.n. (MZUC-UCCC). ARGENTINA: Neuquén, San Martín de los Andes Leg. S. Schajovskoi (4 specimens); Neuquén, Lago Hermoso (8 specimens) (ZSM).

Lachnocephala vellosata: CHILE: Elqui: Coquimbo Leg. J.J. Walker [Holotype, Allotype and 4 Paratypes] (BMNH). Chacabuco: Til-Til, Caleu 6-IX-1992 Leg. M. Cerda; Til-Til, Caleu 12-IX-1992 Leg. M. Cerda; Til-Til, Caleu 26-IX-1992 Leg. M. Cerda. Santiago: Lo Aguirre 02-X-1947 Leg. n.n. Cordillera: El Manzano 12-X-1948 (4 specimens) (*); El Canelo 24-X-1937 (2 specimens) (MZUC-UCCC).
Archiearides pusilla: CHILE: Valparaíso: Chili, Valparaíso summer Leg. T. Edmonds [Syntype] (BMHN). Melipilla: Chile, $34^{\circ} \mathrm{S}$ Br. (900m) 21-X-1956 Leg. B. Heimlich (*) (ZSM).

\section{GEOMETRINAE}

Anomphax gnoma: CHILE: Chili, Valparaíso, Las Zorras XII-I Leg. T, Edmonds [Lectotype] (BMNH) Elqui: Vicuña II-1938 Leg. Ureta (*); Vicuña 22-II-1938 Leg. Ureta. San Felipe de Aconcagua: Fundo Las Majadas (IV Reg.) 21-IX-1997 Leg. M. Hengst. Valparaíso: Viña del Mar 01-V-1953 Leg. n.n; Viña del Mar 02-V-1953 Leg. n.n. Cordillera: Guayacán I-1951 Leg. n.n. (2 specimens). Cautín: Termas de Río Blanco III-1951 Leg. n.n.; Termas de Río Blanco II-1951 Leg. n.n. (MZUC-UCCC).

\section{STERRHINAE}

Cyclophora nanaria: USA: California, San Diego, Torrey Pines State Natural Reserve, Sorrento Valley 02-XI-2005 Leg. N. Bloomfield; Torrey Pines State Natural Reserve, Mesa 30-X-2005 
Leg. N. Bloomfield; California, San Diego, Torrey Pinnes State Natural Reserve, Sorrento Valley 27-VII-2005 Leg. N. Bloomfield (CNC). Illinois, Wayne 21-VI-2010 Leg. S. Scolt; California, San Diego, Tierrasanta 01-V-2013 Leg. N. Bloomfield; California, San Diego, Tierrasanta 16-V-2013 Leg. N. Bloomfield; California, San Diego, Tierrasanta 24-VI-2013 Leg. N. Bloomfield; California, San Diego, Tierrasanta 31-VII-2013 Leg. N. Bloomfield (2 specimens); California, San Diego, Torrey Pines State Natural Reserve, Sorrento Valley 07-VII-2005 Leg. N. Bloomfield; California, San Diego, Torrey Pines State Natural Reserve, Mesa 30-X-2005 Leg. N. Bloomfield; California, San Diego, Torrey Pines State Natural Reserve, Mesa 19-XI-2005 Leg. N. Bloomfield; California, San Diego, Torrey Pines State Natural Reserve, Mesa 14-II-2006 Leg. N. Bloomfield; California, San Diego, Torrey Pines State Natural Reserve, Sorrento Valley 19-VI-2005 Leg. N. Bloomfield; California, Crystal Cove State Park 22-VII-2011 Leg. Biobus 2011 (3 specimens); California, San Onofre State Beach 20-VII-2011 Leg. Bobus 2011; Arizona, Coshise Co. Miller Canyon, Huachuca Mountains 23-VIII-2010 Leg. C. Melton (CBG). JAMAICA: Comwall, Spring Garden S James W Montego Bay 20-III-2011 Leg. L. Reser (ZSM). CHILE: Santiago: Tobalaba 13-X-1946 Leg. n.n. (3 specimens) (*) (MZUC-UCCC).

Cyclophora semirosea: CHILE: Tarapacá: Mamiña 2800mts Iquique IX/X-1951 Leg. L.E. Peña (MZUC-UCCC). Elqui: 7km Sur Vicuña 950m. 27-IX-1997 Leg. H. Thoeny (ZSM). Valparaíso: Chili, Valparaíso XII Leg. T. Edmonds [Syntype semirosea]; Chili Valparaíso XII Leg. T. Edmonds [Syntype notigera] (BMNH). Santiago: La Reina 15-XII-1999 Leg. n.n.; Las Cisternas I- 1950 Leg. n.n.; Tobalaba 16-X-1946 Leg. n.n.; Tobalaba 23-I-1947 Leg. n.n.; Tobalaba 29-XII-1946 Leg. n.n; Tobalaba 20-XII-1946 Leg. n.n. (*); Tobalaba 13-X-1946 Leg. n.n.; Tobalaba 26-IX-1946 Leg. n.n.; Tobalaba 7-XII-1946 Leg. n.n.; Tobalaba 17-XII-1946 Leg. n.n.; Tobalaba 6-X-1946 Leg. n.n.; Tobalaba 13-X-1946 Leg. n.n. (3 specimens); Tobalaba 10-X-1946 Leg. n.n; Tobalaba 19-X-1946 Leg. n.n. Cordillera: Guayacán I-1951 Leg. n.n., Maipo: Buin 8-III-1943 Leg. n.n. Colchagua: San Fernando 28-II-2008 Leg. E. Hernández (2 specimens). Curicó: Curicó 07-II-2015 Leg. M. Ramos. Talca: Panguilemo, La Calor 24-I-2005 Leg. L.E. Parra; Panguilemo, La Calor 2-II-2005 Leg. L.E. Parra; Panguilemo, La Calor 3-II-2005 Leg. L.E. Parra; Panguilemo, La Calor 1-II-2005 Leg. L.E. Parra; Panguilemo, La Calor 2-II-2005 Leg. L.E. Parra. Concepción: Concepción 29-X-1951 Leg. n.n. Coihaique: Aysén, Cerro Castillo 22-I-2007 Leg. L.E. Parra (MZUC-UCCC).

Cyclophora umbrata: CHILE: Chili, Valparaíso XII Leg. T. Edmonds (BMNH).
Cyllopoda claudicula: BRAZIL: Sao Paulo, Ubatuba VIII-2014 (2 specimens) Leg. A. Zheludev (*) (ETHZ).

Rhodostrophia cauquenensis: CHILE: Chili Leg. Felder [4 Syntypes dentilineata] (BMNH). Petorca: Qda. Aguas Claras 600m. 03-IV-1998 Leg. H. Thoeny (ZSM). Colchagua: Chili, Mountains of the Hacienda de Cauquenes [Holotype cauquenesis] (BMNH). Curicó: Cord. Romeral, Los Queñes 10-II-2016 Leg. M. Ramos \& M. Astrosa (4 specimens) (*). Ñuble: Las Trancas 20-I-2012 Leg. G. Moreno (7 specimens); Las Trancas 18-III-2012 Leg. G. Moreno. Biobío: Antuco, P.N. Laguna del Laja 01-XII2006 Leg. C. Zamora-Manzur (MZUC-UCCC).

Rhodostrophia chilenaria: CHILE: Chili [Syntype obscura]. Copiapó: Qda. Las Piovo (-28.1689, -69.8699) 18-I-1998 Leg. H. Thoeny (2 specimens). Huasco: Vallenar, $5 \mathrm{~km}$ N de Huasco 13IX-1996 Leg. A. Ugarte (3 specimens); Quebrada El Pino (1500m) 18-I-1998 Leg. A. Ugarte. Elqui: Pisco Elqui 20-VIII-1997 Leg. A. Ugarte; Pisco Elqui 20-VIII-1999 Leg. A. Ugarte (ZSM). Limarí: Chili, Cord. Ovalle 01-I-1843/31-XII-1843 Leg. C. Gay [Syntype] (MNHNP). Choapa: Cord. Illapel, Huintil 27-XII-1997 (900m) Leg. n.n (MZUC-UCCC). Valparaíso: Chili, Valparaíso IX-I (BMNH). Cordillera: Guayacán I-1951 Leg. n.n. (4 specimens); Guayacán V-1943 Leg. L.E. Peña $\left(^{*}\right)$ (MZUC-UCCC).

Rhodostrophia ferruginaria: CHILE: Curicó: El Radal, Cord. Molina I-1951 (3 specimens) (*). Talca: Curillinque 12-I-1948 Leg. n.n. Ñuble: Las Trancas 14-XI-2001 Leg. L.E Parra; Las Trancas 15-I-1996 Leg. n.n.; Las Trancas 11-I-1996 Leg. n.n.; Las Trancas 8-II-1999 Leg. L.E. Parra (2 specimens). Biobío: Laguna del Laja 01-XII-2006 Leg. C. Zamora-Manzur. Malleco: Nahuelbuta, Rio Picoyquen 22-XII-1962 Leg. Fetis (3 specimens). Cautín: Termas de Río Blanco Cautín II-1951 Leg. n.n. (MZUCUCCC).

Rhodometra sacraria: CHILE: Petorca: Qda. Aguas Claras 600m. 03-IV-1998 Leg. H. Thoeny (ZSM). Talca: Panguilemo, La Calor 03-II-2005 Leg. L.E. Parra; Panguilemo, La Calor 13-II-2017 Leg. L.E. Parra (8 specimens). Ñuble: Ninhue 26-III-2012 Leg. G. Moreno (*); Ninhue 18-II-2011 Leg. G. Moreno; San Fabián de Alico 27-III-2011 Leg. G. Moreno. Biobío: Los Ángeles, Santa Fe, 139m. 20/27-IV-2005 (MZUC-UCCC).

Scopula umbilicata: USA: Texas, Val Verde, Del Río 29-IX-1995 Leg. J. Glaser (*) (CBG). CHILE: Arica: Azapa 26-II-1969 Leg. R. Mendoza; Azapa Grande 14-II-1964 Leg. H. Vargas C. (IDEA).

Recibido: 16.03.2018

Aceptado: 17.05.2018 